so that they willingly become involved. Other colleges assume that all clinicians, as a matter of course, involve themselves in Continuing Medical Education (CME) (CPD). This is a subtle difference, but for them the question of choice does not then arise, and I am not aware of much dissent. Some psychiatrists believe that other colleges do not charge for CME (CPD). Yet any such scheme inevitably involves cost, whether this is absorbed into a general membership subscription or charged as a separate fee, as in the case of psychiatry. The Royal College of Obstetricians and Gynaecolo-gists intends in due course to publish a so called White List of clinicians who have completed its CME programme. I do wonder, in that event, how psychiatrists will fare when the searchlight of public scrutiny will inevitably in turn become focused on us.

It would be splendid if during my second year as Director of CPD I could find myself less involved in trying to persuade clinicians to join CPD, and so be able to devote more time to developing and evaluating the scheme further. The most reliable way to guide me in this challenging task is to participate and thereby provide me with advice based on first-hand involvement in it.

Gethin Morgan, Director of CPD, Royal College of Psychiatrists

\title{
Approved nominations to the Fellowship and Membership under Bye-Law III 2 (ii)
}

It was agreed that the following candidates should receive the Fellowship:

Dr A. J. Abraham, Dr I. K. J. Al-Adhmawi, Dr M. S. Alexander, Dr A. A. Al-Husaini, Dr M. D. Alldrick, Dr Z. Atakan, Dr P. G. Baines, Dr R. W. K. Bamber, Dr J. C. Barnes, Dr D. J. Bevington, Dr M. R. Bhatti, Dr J. Bird, Dr N. R. Bishay, Dr J. P. Boakes, Dr M. J. Bober, Dr D. M. Bowker, Dr S. R. Britten, Dr J. M. Brockington, Dr B. J. Brockman, Dr D. S. Brooks, Dr S. W. Brown, Dr I. Cariapa, Dr H. R. Cattell, Dr A. K. Chaudhary, Dr G. L. Christie, Dr S. Y. Chung, Dr D. J. Clarke, Dr M. J. ClarkeFinnegan, Dr P. J. Connelly, Dr T. H. Corn, Dr J. Dalton, Dr A. S. David, Dr S. Deb, Dr M. Devakumar, Dr N. M. Devaney, Dr F. I. S. De-Zulueta, Dr D. C. Drummond, Dr J.W. Eastgate, Dr C. Feinmann, Dr F. M. Z. Flynn. Dr M. F. Ford, Dr D. P. Forster, Dr J. Freedman, Dr R. C. S. Furlong, Dr K. George, Dr M. Gilmore-McInerney, Dr W. R. Guirguis, Dr V. J. Harris, Dr T. M. Harrison, Dr P. E. HarrisonRead, Dr P. Haydn-Smith, Dr N. L. Holden, Dr W. Y. C. Hung, Dr M. F. Hussain, Dr R. A. Jackson, Dr A. Janca, Dr M. M. Jilani, Dr D. M.
Jones, Dr E. M. Jones, Dr S. Joseph, Dr E. M. Joyce, Dr A. Kearns, Dr D. D. Kohen, Dr B. W. K. Lau, Dr A. S. Lee, Professor G. H. Lewis, Dr S. N. Mahapatra, Dr J. A. Marks, Dr J. P. McKeon, Dr S. Moorey, Dr J. D. Mumford, Dr E. D. O'Callaghan, Dr D. Pariente, Dr J. K. Pasterski, Dr R. C. Peveler, Dr M. P. Philpot, Dr M. J. H. Qureshi, Dr S. Rajkumar, Dr A. J. Ramirez, Wing Cdr G. E. Reid, Dr A. Roy, Dr M. Roy, Dr D. T. Selvarajah, Dr M. R. Shah, Dr P. J. Shoenberg, Dr A. O. Sirag, Dr J. M. A. Smithies, Dr N. J. Suffling, Dr A. F. S. Tanaghow, Dr R. I. L. Tillett, Dr P. M. Trotter, Dr D. Turkington, Dr J. Walshe, Dr P. E. Watson, Dr A. J. Winbow, Dr A. D. Wolhuter, Dr G. K. K. Yu, Dr A. R. Zachary.

It was agreed that the following should be awarded Membership under Bye-Law III 2(ii):

Professor M. Hussain, Dr J. Maratos.

It was agreed that Dr A. A. Voloshanovich should become a Member under Bye-Law III 2 (ii) and at the same time receive the Fellowship of the College. 